\title{
The more-than-human refugee journey: Hassan Blasim's short stories
}

\section{Rita Sakr}

To cite this article: Rita Sakr (2018) The more-than-human refugee journey: Hassan Blasim's short stories, Journal of Postcolonial Writing, 54:6, 766-780, DOI: 10.1080/17449855.2018.1551269

To link to this article: https://doi.org/10.1080/17449855.2018.1551269

册 Published online: 08 Apr 2019.

Submit your article to this journal 준

Џlll Article views: 406

Q View related articles $₫$

View Crossmark data $\asymp$ 


\title{
The more-than-human refugee journey: Hassan Blasim's short stories
}

\author{
Rita Sakr \\ Maynooth University, Maynooth, County Kildare, Ireland
}

\begin{abstract}
This article addresses the representation of forced and clandestine migration in some of Hassan Blasim's short stories within an interdisciplinary conceptual framework that brings together theories of biopolitics, ecocriticism, human rights discourse, heterotopia, and the aesthetics of "nightmare realism". Blasim's short stories offer new opportunities to address territoriality, life and truth at their limits in real and imagined sites where forest and border, human and non-human meet to suggest more-than-human futures for the paradoxical project of reclaiming human rights. By analysing Blasim's unique representational techniques, through which he mediates material and discursive violence within a combined biopolitical-ecological framework, the article also investigates the potentials and limitations of a more ecologically attuned perspective on freedom of movement and community, based on the claims of the environment rather than the nation.
\end{abstract}

\section{KEYWORDS}

Hassan Blasim; migration; more-than-human; biopolitics; ecocriticism; nightmare realism

According to post-Foucauldian readings of biopower, the management and control of human migration to ensure human security are not only entrenched violent anthropocentric mechanisms and metaphors, but also mediators of the fragile category "human". Furthermore, in recent postcolonial readings of forced and clandestine migration, the public representational frameworks for the asylum-seeker are read as mediating the "trope of the infrahuman" (Farrier 2011, 24). This nexus of representational violence and fragility is accentuated whenever the ecological question is taken into consideration. Transdisciplinary investigations of the intersections between biopolitical and ecological research in recent years have produced a plethora of impactful work, such as the volume Humans, Animals and Biopolitics: The More-than-human Condition, edited by Asdal, Druglitrø, and Hinchliffe (2017). Among these essays is an insightful reading of the exiled Libyan writer Ibrahim al-Koni's two desert nomad novels, Gold Dust (2008) and The Bleeding of the Stone, (2002), as imaginative explorations of "the multispecies singularities of persecuted desert dwellers" that "situate the exterminationist politics of the state amid possibilities for biopolitical alternatives" (McHugh 2017, 174). While al-Koni's texts provide unique fictional material for such transdisciplinary research into the ethico-political dynamics of the representation of desert nomadism in Libya, we now have a varied corpus of Arab migrant and refugee 
narratives that can enrich and expand the horizons of our understanding of a different kind of displacement from the Arab world, specifically relating to post-conflict clandestine movement across Europe, within a similarly multifaceted framework. In this context, the nexus forest-border emerges as a particularly significant counterpart of the desert.

Reading the travel diary of Iraqi poet and art critic Farouq Yousef La Shay' La Ahad: Yawmiyyat fi al-Shamal al-Urubi (Nothing and nobody: The diary of an Arab in Northern Europe; Yousef 2007), Johanna Sellman (2014) astutely notes that while the "solitary experiences that the narrator describes in the forest are [...] not divorced from the larger contexts of border security and war", Yousef

imagines the forest [in Sweden] as a space that can heal his trauma because it can conceal, if not erase, the traumatic memories that induced it. As such, the forest offers an idealized and enclosed sanctuary not governed by political conflicts, boundary-making practices, and the policing efforts of "Fortress Europe". (n.p.)

A similar nexus of more-than-human encounters and transformations in real and imagined forests punctuating the trajectories of forced and clandestine migration to Europe can be found in Hassan Blasim's collections of short stories, The Madman of Freedom Square (Blasim [2009] 2016) and The Iraqi Christ (Blasim 2013), which are brilliantly translated into English by Jonathan Wright. The Iraqi-born writer now lives in Finland where he was granted refugee status after a clandestine journey through Europe. Intensifying rather than healing traumatic experiences, the forestborder in Blasim's work is the imaginative locus of a complex exploration of the biopolitical and ecological implications of material and discursive violence wielded against clandestine migrant bodies. In this context, Blasim employs the density and paradoxical excesses of animal metaphors to investigate the implications of this violence.

Introducing "Zoocriticism and the Postcolonial", the third part of their influential Postcolonial Ecocriticism, Huggan and Tiffin (2010) address the ways in which "the history of human oppression of other humans is replete with animal metaphors and animal categorizations frequently deployed to justify exploitation and objectification, slaughter and enslavement" (135). While Huggan and Tiffin examine various zoocritical world-literary engagements that can be read alongside postcolonial interpretations of forest landscapes, Blasim's short stories that focus on forced and clandestine migration offer new opportunities to address territoriality, life and truth at their limits in real and imagined sites where forest and border, human and non-human meet to suggest morethan-human futures for the paradoxical project of reclaiming human rights. These stories also allow us to revisit the implications of heterotopia in the age of the refugee, in the aftermath of its seminal conceptualization in Foucault's (1986) "Of Other Spaces". In this article I will primarily focus on two short stories by Blasim, "The Truck to Berlin" from The Madman from Freedom Square and "Why Don't You Write a Novel Instead of Talking About All These Characters?" from The Iraqi Christ. It is essential to begin by tackling the significance of what Blasim (2016) calls an aesthetic of "nightmare realism" in order to get a sense of the unique representational techniques through which he mediates material and discursive violence in a combined biopoliticalecological framework. 


\section{An aesthetic at the limits of representation}

Reading Blasim's short stories of "dismembering violence" that are set in Iraq in the larger context of post-2003 Iraqi narratives, Haytham Bahoora (2015) argues that these stories "disorient the reader, using a dark, fragmented aesthetic to create a terrain of horror where violence is pervasive, brutal, and ordinary" (188). Bahoora ultimately relocates this disorienting style within a familiar framework by reminding us that "literary recourse to the metaphysical, whether through the subconscious, nightmares, or the supernatural, are [sic] frequent stylistic conventions of post-2003 Iraqi literary production, narrating a terrain of unspeakable violence and its many afterlives" (185). As an approximation of a specific literary style and technique, Bahoora places this literary recourse to the supernatural within the tradition of postcolonial gothic fiction and interprets it as a response to the failure of literary realism to represent the "sectarian violence" that impacted the Iraqi landscape after 2003 (200). It is of course possible to extend the scope of Bahoora's argument and note the impact of the postcolonial gothic not only on Blasim's stories set in Iraq, but also on those that portray clandestine migrants and asylum-seekers. Aspects of resistance to realism in Blasim's writings can be traced beyond the international postcolonial gothic and the specifically Iraqi rendering of this aesthetic when we take into consideration the supplementary tradition of Nordic short fiction in which his work can also be placed, given his refugee literary life in Finland. Introducing the volume The Dark Blue Winter Overcoat \& Other Short Stories from the North, to which Blasim contributed the aptly titled "Don't Kill Me, I Beg You. This Is My Tree”, the Icelandic writer Sjón, in an interview with Ted Hodgkinson included in the introduction, argues that the contemporary Nordic short story is "alive to the possibilities of human transformation, rooted in the metaphysical world of folklore and fairy tale" and creative of "a world where metamorphosis and transcending the borders of the 'real' and the 'true' are more than just possible, they are tools for survival in harsh natural surroundings or a failing community" (Sjón and Hodgkinson 2017, 3). While the Nordic folkloric corpus might not be the primary resource for Blasim's representational spaces, its liminal aesthetic of metamorphosis mediating precarious communal bonds in a dangerous and endangered environment is particularly relevant.

Robin Yassin-Kassab (2013) traces yet another literary genealogy for Blasim's aesthetic: "The collection is more generally Bolaño-esque in its visceral exuberance, and also Borgesian in its gnomic complexity" (n.p.). His view paradoxically brings us closest to an understanding of Blasim's aesthetic by highlighting the excesses of its global magical realist connections. Blasim's border stories might remind us of Roberto Bolaño's (2009) exploration of violence in a re-imagined Ciudad Juarez in his monumental novel 2666. Worthwhile as these comparisons may be, they comprise partial connections that do not capture the breadth of Blasim's stylistic innovations. In an interview with Margaret Litvin and Johanna Sellman for Tank magazine, Hassan Blasim confronted critics' fascination with his style and their attempt to place it in a magical realist tradition: "They say to me, for example, 'Your style is magical realist like Marquez.' And I say: 'No, I write nightmare realism.' And they nod, $m m-h m m$, and write in the newspapers: 'nightmare realism"' (Blasim 2016, n.p.). The playfulness of Blasim's retort to his critics corresponds to the terminological fluidity of the new aesthetic of "nightmare realism" when it is compared with its counterpart. In magical realism, 
the emphasis is on the "thereness" of the non-human, the counterfactual, otherness. Spaces are hybrid: opposite properties coexist. The temporal regime is mainly one of regressiveness and simultaneity. Characters are not single and central, but come in groups of two or more, or from communities. The story-line is rendered problematic, freed from logical connections, and working only by means of internal causality. Dominant themes centre on process-formation and carnivalization: routes, journeys, growth, initiation, death and rebirth, mutation, metamorphosis. (Linguanti 1999, 6)

Blasim's writing brings together almost all these themes and techniques while distinguishing itself by introducing the crucial variable of the nightmare. In her study Nightmare: From Literary Experiment to Cultural Project, Dina Khapaeva (2012) notes that

[a]ll authors who write about nightmares have wondered about the boundaries between nightmare and life and what the difference is - if indeed there is one - between reality and fiction $[\ldots]$. Experimentation lies at the heart of the writing of authors in whose writing the investigation of the nightmare plays a major role. (4)

The aesthetic complexity of Blasim's project articulates a challenge to the unrepresentability and excesses of the horrific realities it confronts. Perhaps the metafictional opening comments in "The Truck to Berlin" on the narration of the clandestine journey best express the contours of Blasim's radically heterotopic representational space:

A major part of the story would make a good experimental radio piece. For sure most readers would see the story as merely a fabrication by the author or maybe as a modest allegory for horror [ ... ]. What I need to do is write this story, like a shit stain on a nightshirt, or perhaps a stain in the form of a wild flower. ([2009] 2016, 67)

\section{"The Truck to Berlin"}

The key horror events that open and close Blasim's stories occur in thick and vast forests that are adjacent to national borders. Sellman (2014) aptly refers to the various meanings of ghaba (the original Arabic word for forest) in her discussion of Yousef's diary, noting among its derivatives the Arabic terms for abandonment and for being concealed from sight. The Qutr al-Muheet, Aqrab al-Ma'arif and Munjid dictionaries define the verb phrase ghaba 'an biladihi as travelled, ghayyabahu as exiled or buried someone, and ightabahu as having committed an act of slander. Condensing these various implications of the term in the Arabic text, the forest hence becomes the most conceptually dense geographical anchor for the exploration of the perilous dynamics of forced and clandestine migration as well as their related geopolitical and representational parameters. In "Ali's Bag” in The Madman of Freedom Square, we read that

[a]s soon as the group set off into the forest behind the smuggler, some border guards appeared and began shouting at the group, ordering them to stop. [ ... ] They fled between the trees in the darkness of the thick forest, letting the branches scratch their faces and rip their winter coats. (Blasim [2009] 2016, 64)

It is in the Greek forest that Ali loses his most treasured possession from his past life in Iraq, the head of his dead mother - a counter-necrophilic trope. 
In comparison with "Ali's Bag", “The Truck to Berlin" presents a more philosophically and ethico-politically expansive exploration of violence in the forest-border setting. The story focuses on an embedded narrative by "Ali the Afghan" of the clandestine journey of "thirty-five young Iraqis", transported by a Turkish smuggler in "a closed truck exporting tinned fruit from Istanbul to Berlin" (Blasim 2016, 68). They are deserted by the smuggler and discovered by the Serbian police "on the edge of a small border town surrounded by forest on all sides" in an "abandoned poultry field" (72). The police find 34 dismembered corpses while a "bloodstained youth" (73) escapes from the truck into the forest and is reported to have crossed the border into Hungary. In this context, a zoomorphism with a vengeance unravels the excesses of the anthropomorphic imagination, but this is not a simple reversal of the terms of a binary or of the metaphorical dialectic. Rather, it is an engagement with the impacts of combined material and discursive violence. While those who tread the "paths of secret migration" (Blasim [2009] 2016, 72) are smuggled as "human cattle of the East to the farms of the West" (67), there is here no moment of arrival or complete transformation and therefore no closure of ethico-political questions of responsibility.

The story mediates the now-familiar paradigm, from globalization and migration studies, of the containment and invisibility of illegal migrant bodies in contrast to the free flow of commodities and capital. However, the epistemologically reassuring stability of the boundaries between the human and non-human is undermined when the bodies leave the biopolitically managed network of connected cities and enter liminal space-times of abandonment at the Serbian forest-border. Amnesty International (2015) has recorded extensive ill-treatment and exploitation by the Serbian police of asylumseekers and migrants who seek the partial protection afforded on the Serbian side of the Serbia-Hungary border, particularly in an area referred to as the "jungle" - a disused brick factory, surrounded by wetlands and overgrown fields” (46).

The setting emphasizes the mutual encroachment of inhabited space and wilderness, national territoriality and environmental fluidity. What Giorgio Agamben (2000) refers to as the violence committed against the "naked life" (6) of the camp refugee is reduced to a disembodied sound in this radical non-place-time:

When they heard the scream, they tried to imagine the source of this voice, neither human nor animal, which had rocked the darkness of the truck [... ]. It seemed that the cruelty of man, the cruelty of animals and legendary monsters had condensed and together had started to play a hellish tune. (Blasim [2009] 2016, 72)

The vagueness of the pronoun "they" confounds the categories of witness, victim and perpetrator of the violence in as much as it highlights the complexity of the question of responsibility. Moreover, the paradoxical deferral and condensation of agency disrupts the human/non-human binary that is familiar from psychoanalytical, mythological, ecological and biopolitical perspectives on violence committed in liminal space-times occupied by travelling yet trapped bodies.

The spatio-temporal and ontological indeterminacy of the violence imaginatively articulates a challenge to Agamben's double ethico-political project of reclaiming the "bare life" $(2017,8)$ of the refugee and envisioning Europe as "an aterritorial or extraterritorial space in which all the (citizen and noncitizen) residents of the European states would be in a position of exodus or refuge" (Agamben 2000, 23-24). ${ }^{2}$ Blasim's nightmare-realist vision 
not only complicates this project by exploring the dystopian implications of extraterritoriality; it also undermines a firmly biopolitical explanation of the violence against the "naked life" of the clandestine migrant by introducing the uncertainties of the ecological framework.

"The Truck to Berlin" thus invites an intersectionalist approach that highlights the possibilities and limitations of transdisciplinary explorations of more-than-human justice through the literature of clandestine and forced migration. The Serbian police record of a "young man soaked in blood [who] jumped down from inside and ran like a madman towards the forest" (Blasim 2016, 73) clashes with a lone policeman's account that "as soon as the man reached the forest he started to run on all fours, then turned into a grey wolf, before he vanished" (73). In this context, Agamben's work opens up an approach to the ethico-political implications of the liminality of the man/ wolf at the crossroads of biopolitical and ecological imaginaries:

a monstrous hybrid of human and animal, divided between the forest and the city - the werewolf - is, therefore, in its origin the figure of the man who has been banned from the city. That such a man is defined as a wolf-man and not simply a wolf [ ... ] is decisive here. The life of the bandit, like that of the sacred man, is not a piece of animal nature without any relation to law and the city. It is, rather, a threshold of indistinction and of passage between animal and man, physis and nomos, exclusion and inclusion. $(2017,89)$

After they open the back door of the truck, the policemen encounter an extreme scene of violence that they seek to contain in the heterotopic framework of the strictly non-human:

In the truck there were thirty-four bodies. They had not been torn apart with knives or any other weapon. Rather it was the claws and beaks of eagles, the teeth of crocodiles and other unknown instruments that had been at work on them. The truck was full of shit and piss and blood, livers ripped apart, eyes gouged out, intestines just as though hungry wolves had been there. (Blasim [2009] 2016, 73)

What the policemen try to resist is the realization that "such a man is defined as a wolfman and not simply a wolf [ ... ] is decisive here" (Agamben 2017, 89). The ethicopolitical parameters of this encounter lie at the frightening threshold of exclusion and inclusion thus challenging specieisist and therefore racist thinking that thrives on what Huggan and Tiffin describe as cultural imaginaries of "separate subjectivity" $(2010,136)$. As Foucault (2009) reminds us, a concept of identity that insists on the same and fears complex subjectivity is the central dynamic in the construction of madness.

The lone policeman's dissenting account re-imagines the scene not through the escape of the surviving "madman" across the border into Hungary from the scene of carnage committed by "hungry wolves", but rather at the threshold of the forest where he morphs into a wolf. In the world of clandestine and forced migration literature, we may view this lone policeman, who insistently tells his wife that he is "not mad" (Blasim 2016,73 ), as the postmodernist yet still anxiously humanist alter ego of a Marlow who is troubled by the duty to bear witness to the horror of Europe's new heart of darkness but resists a full articulation of the moral and political implications of the extraterritoriality of violence against secretly migrating bodies. Achebe's (1988) argument that in Conrad's Heart of Darkness Africans became "mere metaphors for the break-up of one petty European mind" (257) can thus be revisited here to argue that "The Truck to Berlin" magnifies the violence of metaphor and the metaphorical space of violence 
against the other/alien body and implies that participating in or witnessing without bearing witness to such violence are forms of complicity in representational madness. ${ }^{3}$

Through the policeman's dissenting account, Blasim displaces the speciesist perception of non-human violence against indistinct "bodies", a perception that is removed from a framework of accountability and also of what Judith Butler (2010) calls "grievability", by introducing the frightening possibility of cannibalism. Aptly evoking the cannibalistic trope of Conrad's narrative, Blasim's story extends the implications of the epistemological paradox and moral ambiguity in the nightmare-realist realization of the cannibalistic metaphor. That we only get a description of the aftermath of the violence subversively mimics what Huggan and Tiffin identify as the selective focus in "classic European encounters with cannibalism: the remains but not the deed, the mediated (hearsay) but never the direct (eye-witness) report" (2010, 168). However, against the othering strategies implied in the cannibalistic scenario, Blasim keeps agency in flux as indeterminate bodies and threshold moments of mutation displace the human/nonhuman binary. The radical dimension of this act of alternative consciousness lies in bringing the ecological dynamic to bear on the biopolitical in order to transcend the binary. This acknowledges what sociopolitically informed environmental research views as the possibility of "doing politics differently" by allowing the complexities of "indeterminate bodies" to influence "human questioning" and decision-making (Waterton 2017 , 103). Significantly, the question of responsibility (individual/collective, human/ non-human) is unresolved while the dismembering impact of the violence is presented as the only certainty: "Thirty-four young men had become a large soggy mass of flesh, blood and shit" (Blasim [2009] 2016, 73).

Blasim's representation of dismembered bodies in the truck heading to Berlin is reminiscent of his multiple raw portrayals of scenes of carnage in Iraq in stories like "The Reality and the Record" and "The Corpse Exhibition" in the first collection, and "The Iraqi Christ", the eponymous story of the second. Notably, "The Corpse Exhibition" offers another "nightmare-realist" exploration of the intertwined ethico-political horizons of extreme "creativity" in biopolitical and ecological violence whereby one of the "boring and frustrating lessons" taught to the "professionals" of the corpse exhibition is that "it would not be possible to bring about peace on this earth without sacrificing laboratory humans as well” (Blasim [2009] 2016, 48). In reading Blasim's work alongside other Iraqi narratives of war, Bahoora argues that

[t] he centrality of representations of dismembering violence to the narration of post-2003 Iraqi identity raises a series of questions about the role narrative fiction plays in constructing a history and experience of structural violence for which there has been no political, legal, or historical accountability. $(2015,188)$

In sketching a literary-geography of dismembering violence across Iraqi warscapes and clandestine forced migration routes and its heterotopic displacement outside frameworks of historical accountability through the discursive exploitation of speciesist binaries, Blasim's stories invite urgent questions on the implications of Iraqi extraterritorial violence at the crossroads of literary-critical theory, international law, political philosophy, contemporary European politics and the ethics of more-than-human justice. 
These questions highlight the limitations but also the potential reconfiguration of a human-rights-orientated reading when reviewed through an adjusted ecocritical lens. Such a perspective insists on the material and symbolic relevance of the more-thanhuman perspective to the fraught project of human rights. At the heart of this conceptualization is the connected issue of alternative perception and representation. To address this it is necessary to go back to the beginning of "The Truck to Berlin". The frame narrator sets up from the start an implicit link between ecological and biopolitical contexts of interpretation and the counter-representational aesthetic of "nightmare realism" in the embedded narrator's Ali the Afghan's story: "in my view the world is very fragile, frightening and inhumane" (Blasim [2009] 2016, 68). The framing text poignantly presents the question of the ethics and politics of the representation of the clandestine asylum-seeking journey:

My view is that as far as the public is concerned such mass drownings are an enjoyable film scene, like a new Titanic. The media do not, for example, carry reports [ ... ] about what the armies of European democracies do when at night, in a vast forest, they catch a group of terrified humans, drenched in rain, hungry and cold. (68)

Agnes Woolley (2014) notes in her study of asylum narratives in Britain that "oscillating between invisibility and overexposure in the public sphere, forced migrants have an ambivalent relationship to the aesthetic forms that seek to represent them, one which touches on questions of communicability, visibility and ethics" (13). One might argue that there is an excessively cynical dismissal of compassion and solidarity in the description of a presumably western audience for whom "mass drownings are an enjoyable film scene". But what is at stake in Blasim's text is the confrontation with the crisis of representation concerning what has been dubbed as "the refugee crisis" in the mass media. This pertains to the sensationalism and trivialization of the loss of human life and the failure to represent abandonment and assaults on "bare life" in the heterotopic spaces of the Mediterranean and the Balkan forest-border where accountability for not saving and/or violating human life is blurred by extraterritoriality. While the framing text establishes an encounter of specifically "terrified humans" and "armies of European democracies" as clear referents for what could be (even if it often fails to be) represented in the media, the aftermath in Ali the Afghan's story of the "twenty-four bodies", the "hungry wolves" and the man "turned into a grey wolf" marks the unhinging of the representational boundaries of the speciesist imaginary at the limits of territoriality, life and truth.

The political geography that Blasim's story traces is punctuated not only by the heterotopic forest, but also by two other heterotopia that occupy key junctures along the clandestine Balkan route and that have become even more relevant with the mass displacement of Syrians who have swelled the numbers of asylum-seekers since 2011. These two spaces are Berlin and the Serbian-Hungarian border that, as "heterotopia of compensation", are the subject of clandestine asylum-seekers' dreams and nightmares respectively but that, unlike the boat in the Mediterranean, are rooted in representational anxieties concerning territoriality. In the late 1960s, Foucault argued that "in civilizations without boats, dreams dry up, espionage takes the place of adventure, and the police take the place of pirates" $(1986,27)$. Half a century later, transnational surveillance and aggressive policing of mobility have clearly transcended the 
geographical, biopolitical and ecological distinctions of boat/truck and sea/land while metaphor still unravels cross-border landscapes of representational violence and resistance.

\section{“Why Don't You Write a Novel, Instead of Talking About All these Characters?"}

In The Iraqi Christ, Blasim expands the political-geographical scope of his exploration of the clandestine asylum-seeking journey at the intersection of biopolitical and ecological frameworks by returning to the crucial setting of a forest near the Hungarian border but including the supplementary heterotopic nexus of the refugee reception centre, the quarantine, the hospital and the cemetery. Examining "Double Images: Refugee Crises and the Afterimages of Endless War”, Angela Naimou (2016) argues that

[w] hether reporters name it the "European migrant crisis" or the "European refugee crisis" to invoke an ethics of hospitality or a politics of exclusion [ ... ]. The refugees are subject to violence both spectacular and banal and are criminalized for attempting to minimize the doubled violence inflicted upon them. (227)

Blasim revisits the under-represented space-time of "what the armies of European democracies do when at night, in a vast forest, they catch a group of terrified humans, drenched in rain, hungry and cold" (Blasim [2009] 2016, 68) to address "legalized, chronic, and routinized violence" (Naimou 2016, 227) against clandestine migrants and asylum-seekers. Unlike "The Truck to Berlin", "Why Don't You Write a Novel, Instead of Talking About All These Characters?" begins with a moment of arrival and a confrontation with the implications of policed territoriality. It opens with the scene of asylum-seekers making their clandestine crossing of a forest at the RomanianHungarian border - on the other side of the now more notorious Serbian-Hungarian border where the Hungarian police have recently stationed thousands of "borderhunters" and where border guards take selfies with beaten and humiliated migrants (Than 2017, n.p.) in the latest instalment of neo-liberal authoritarianism. In March 2017, Reuters reported that "Hungary also passed a law to detain migrants in camps along its border, a step the United Nations said violates EU humanitarian law and will have a 'terrible physical and psychological impact' on asylum seekers" (Than 2017). The report quotes regional police chief Attila Piros who explains that the rules governing the actions of "border hunters" are the same as those for regular police:

to "break resistance" but only as a last resort. He said any force must be proportionate and justified. "One of the most important things in this six-month training that we teach as law but in fact has moral and ethical foundations is that criminals are human beings, everybody has human rights." (Than 2017)

While the term "border hunters" inscribes unapologetically the non-human as a target for the boundary-enforcing operation hence refracting the "hungry wolves" imaginary encountered in "The Truck to Berlin", the police chief's statement paradoxically emphasizes the legal foundation of the disciplinary criminalization of the clandestine movement while resorting to a vague language of universal human rights. 
Against the exclusionary spatiality of the international border, the forest at the start of Blasim's story tentatively contests territoriality and its associated binary configurations. And by blurring the boundaries between the human and the non-human as they both cross its space-time, the forest suggests a more ecologically attuned perspective on freedom of movement, based in the claims of the environment rather than the nation. Yet a utopian conceptualization of the extraterritoriality of the forest is immediately disrupted by Blasim's introduction of a militarized disciplinary force combining the human and non-human as the Hungarian army dogs sniff a corpse among the asylumseekers. The biopolitical parameters of the heterotopic wilderness and related predatory dynamics are thus reasserted as the clandestine migrating human body is exposed and immobilized in discipline and death while the non-human force is co-opted by the nation state.

Mapping the biopolitical management of the asylum-seekers' bodies, Blasim's story traces a tight political geography of border enforcement comprising the army post, the quarantine section of the refugee reception centre, and the hospital that is close by the cemetery on the outskirts of the town. An obvious reference may be made here to Foucault's (1977) thoughts on the panopticon in Discipline and Punish to explain this architecture of absolute control. ${ }^{4}$ Yet contemporary refugee studies offer a more productive framework to address this spatiality. In "Humanity as an Identity and its Political Effects (A Note on Camps and Humanitarian Government)", Michel Agier (2010) identifies four types of encampment, among which the "second type, represented by the retention centers in Europe which are a group of 'sorting offices,' are located at the borders themselves and serve as a form of lock on the movement of different types of migrants and refugees" (36). In these spaces, the common experience is of

[i]mmobilization, [ ... ] the juridical hole which makes spaces of exception become ordinary; the registration of people with files, cards, and fingerprints; the difficult access to these places, which are remote and isolated, controlled by public service or private police; and the violence committed inside, which is rarely mentioned. (36)

The refugee reception centre, as a space that receives the victims of war and persecution, presupposes a universalist ethics of hospitality (receives) and humanitarianism (offers refuge) - here universalist in the legal sense of adhering to the Universal Declaration of Human Rights and international conventions on refugee rights. However, in the contemporary Hungarian case that may be extreme but it is not exceptional in a global framework of refugee management; it mediates an exclusionary nationalism that detains the non-citizen within a spatiality of bare life. Such displacement of ethico-political commitments from purported reception or retention to actual detention invites us to revisit Agamben's argument that

the separation of humanitarianism and politics that we are experiencing today is the extreme phase of the separation of the rights of man from the rights of the citizen [ ... ] at the same time that humanitarian organizations [ ... ] maintain a secret solidarity with the very powers they ought to fight. $(2017,110-111)$

Blasim's narrative anticipates the extreme politicization, through Viktor Orban's nationalist rhetoric and militarization of the Hungarian response, to the primarily humanitarian aspect of the recent influx of asylum-seekers in the larger context of 
the hardening of the European Union's stance on clandestine migrant movement. In March 2017 the Hungarian government formally relinquished the humanitarian model of the reception centre when it passed a bill to detain asylum-seekers in converted shipping containers that have been condemned by humanitarian non-governmental organizations (NGOs) as not fit for humans (Nielsen 2017).

Blasim's story indicates that the refugee reception centre is heterotopically situated as "other" to the inaccessible communal space of the town, thus refracting the politicalgeographical dynamics of what has been referred to as the Hungarian "transit zones" at the border (Nielsen 2017). More radically, the refugee reception centre anchors the crucial part of the asylum-seeking journey from the ecological border of the town, the forest, to the biopolitical one, the hospital that is adjacent to the classically heterotopic space of the cemetery, thus creating a paradoxical symmetry of desire, discipline and death - ecopolitics, biopolitics and thanatopolitics. The asylum-seekers are interpellated by the biopolitical order of what has been referred to in globalization studies as "governmobilities" (Baerenholdt 2013) and are reduced to a series of markers of the discontented south including the Iraqi, the Kurd, the Afghan, the Sudanese, the Nigerian, the Moroccan, the Somali (Blasim 2013, 93) - labels for literally bare bodies displaced from conflict-ridden, socio-economically vulnerable or failed nation states.

Blasim's narrator describes how

the woman made a hand gesture, telling me to take off my underpants. Yesterday they took our stool samples, today they're examining our skin. She made a note in the papers in front of her, then made a little upward gesture with her finger. I pulled up my underpants. She waved towards the door without looking up at me. [ ... ] We were a new group of inmates. $(2013,91,92)$

The spatial dynamics of the refugee reception centre undermine the binary opposition that Foucault sets up between two main modes of access to heterotopic space: "Either the entry is compulsory, as in the case of entering a barracks or a prison, or else the individual has to submit to rites and purifications" $(1986,7)$. As a seeker of a heterotopic space of compensation for the death-ridden nation from which he flees, the refugee in Blasim's short story not only enters a carceral space that is alienated from a community of rights-endowed citizens, but also becomes an "other space" reduced to a naked combination of the ethnoracial and the biological: skin and excrement.

The asylum-seekers are moved from the army post to the "dirty and crowded" quarantine from which lives are flushed out to the "isolation of the hospital on the outskirts of the town" (Blasim 2013, 93). Foreshadowing with a difference the discourse of hygiene and bare life in this short story that features clandestine movement across the border of a presently neo-liberal authoritarian state, the opening story in The Madman of Freedom Square, titled "The Reality and the Record", features an Iraqi asylum-seeker in the social democratic context of Malmö, Sweden, who after being admitted to the refugee reception centre is subject to medical tests; "then they gave him a room, a bed, a towel, a bedsheet, a bar of soap, a knife, a fork and spoon, and a cooking pot" (Blasim 2013, 1; emphasis in original) before eventually admitting him to a psychiatric hospital. Here the magisterial work of Roberto Esposito (2013) on biopolitics, immunization, hospitality, community and violence provides us with the theoretical platform to address this crucial repetition with a difference in the tensions 
between hospitality and immunity across variants of European states' responses to the contemporary "refugee crisis" and its multiple re-imaginings by Blasim:

immunity (or in Latin, immunitas) is the opposite of communitas. Both words derive from the term munus, which means "gift", "duty," "obligation," but communitas is affirmative while immunitas is negative. Thus, if the members of the community are characterized by an obligation to give a gift, by this law to care for the other, immunity implies the exemption or exception from such a condition. (Esposito 2013, 58-59)

Crucially, Blasim embeds the communal-immunitary paradox in a framework that transcends the space-time of the refugee reception centre and encompasses a larger political geography of violence against what is placed literally or metaphorically outside an area of rights and obligations associated with the human. The narrator remembers how in his childhood his family "lived in an area called Air Force Square, close to a military airfield. It was a dirty area teeming with mice, cockroaches and flies" (Blasim 2013 , 97). He describes how "[e]veryone tried to get rid of the mice, but in vain" through various violent methods, including the account of his sister who "like the other women in the neighbourhood, preferred boiled mice to bleeding mice" (97). This embedded narrative functions as a "nightmare-realist" allegorical refraction of the movement of the asylum-seekers from the army post to the "dirty and crowded" quarantine then the "isolation of the hospital on the outskirts of the town". In both contexts, an immunitary discourse of dirt and cleanliness determines the parameters of exclusion of both the dehumanized asylum-seeker and the non-human from a bordered community that fears infection and tellingly prefers to get rid of the threat through violence that leaves no marks of blood. Blood implies not only contamination, but also the acknowledgement of a shared vital body fluid with the violently excluded life in both the biopolitical and ecological frameworks.

This ecocritically significant theme re-emerges when the narrator sees a caged mouse on a train and reads a newspaper story about a fugitive rat whose urine poisoned a Belgian woman on a boat (Blasim 2013, 99). Interestingly, the Oxford English Dictionary lists "fugitive" as one of the synonyms of "refugee"; the English translation of the story thus emphatically links the entrapment and escape of the non-human to the detained "bare life" of the clandestine migrant whose mobility is criminalized. There is here also a metadiscursive allegory on the conflicting roles of the mass media and literature in alternately contributing to dehumanizing and reclaiming the human. More importantly, the embededdness of the nightmarerealist mouse-rat metamorphosis in the poignant refugee narrative signals that, in the face of the epistemic and ecological violence of the binary human/non-human, and at the biopolitical interface of dehumanizing violence and the feared dehumanized life, there is no "other space" to settle into clean citizenship gated away from the poison of the newly wretched of the earth or what Blasim portrays as the morethan-human "breed that's chased forever" $(2013,112)$ in his similarly ecocritically important short story "The Dung Beetle".

Various progressive ethico-political possibilities can be envisioned in this imagined liminality and fragility of the forcibly displaced as more-than-human in Blasim's fiction. This may imply an ongoing engagement with what Dobson (2015) identifies as the question of whether 
the ethical act in this context consist[s] of arguing for the full extension of the human and hence human rights - to bodies that are otherwise denied them, or might neoliberal logic be more soundly challenged by contesting the logic of the human itself, thereby denying the power of those who wield the term's definition? (268)

The horizons of such questioning may be close to Butler's call to address “questions regarding the 'human animal' and how that conjunctive (and chiasmic) existence is to be understood", to reach a "recognition of precariousness as a shared condition of human life (indeed, as a condition that links human and non-human animals)" (2010, 13). Blasim's short stories do not offer easy answers to these persistent philosophical queries but rather confront the reader with a heightened and sustained sense of a crisis of representation urging the need to create imaginative responses.

Esposito reminds us that "[e]verywhere we look, new walls, new blockades, new dividing lines are erected against something that threatens, or at least seems to, our biological, social, and environmental identity" $(2013,59)$. The inevitable result is that "[t]he risk of contamination immediately liquidates contact, relationality, and being in common" (59). The good sense that an alternatively "untimely critique" (Brown 2005, 21) of the "nightmare-realist" narrative of the clandestine asylum-seeking journey in Blasim's short stories reintroduces into our moment of crisis is hence twofold. Blasim masterfully achieves an imaginative tour de force that allows us to explore the necessary conceptual journey through and beyond what Nick Vaughan-Williams (2015) charts as the interconnected "Foucaultian biopolitics", "Agambenian thanatopolitics" and "Derrida's concept of zoopower" in the study of Europe's border crisis. This achievement is at least partly based in Blasim's own aesthetic performance of contamination of recognizable stylistic and representational techniques and frameworks to engage the ethico-political paradoxes of munus and to revisit hospitality through the imagined space-times of biopoliticalecological relationality beyond a bordered vision of territoriality, life and truth.

\section{Notes}

1. Here I follow a recent scholarly trend to address "biopolitics" not only from the perspective of Foucault's (1978) conceptualizations in the first volume of The History of Sexuality, but also taking into consideration his crucial remarks in his Lectures at Collège de France delivered in the 1970s (2010), as well as the work of Thomas Lemke (2011) and Lemm and Vatter's (2014) edited volume on the topic.

2. For a reconsideration of the questions raised by Agamben from the perspective of Hannah Arendt's foundational contributions to the field, see the articles by Patricia Owens (2009) and Etienne Balibar (2007).

3. In her article on Blasim's "The Reality and the Record", Nadia Atia (2017) notes that in the story, "'the horror' (translated from the Arabic الفنز, which might mean fear, dread, or fright, but also terror or a feeling of foreboding) cannot but evoke the final words of Joseph Conrad's Kurtz in an English language literary context" (10).

4. See, for example, Diken Bülent's (2004) readings of panopticism in relation to refugee camps.

\section{Disclosure statement}

No potential conflict of interest was reported by the author. 


\section{Notes on contributor}

Rita Sakr is lecturer in postcolonial and global literatures at Maynooth University, Ireland. She is the author of Monumental Space in the Post-Imperial Novel: An Interdisciplinary Study (2012), and of "Anticipating" the 2011 Arab Uprisings: Revolutionary Literatures and Political Geographies (2013). She is co-editor of The Ethics of Representation in Literature, Art and Journalism: Transnational Responses to the Siege of Beirut (2013) and James Joyce and the Nineteenth-Century French Novel (2011) and co-director and co-producer of White Flags (2014). Her current monograph project is titled "Global Arab Literary Geographies".

\section{References}

Achebe, Chinua. 1988. “An Image of Africa: Racism in Conrad's Heart of Darkness.” In Heart of Darkness: An Authoritative Text, Background and Sources Criticism, edited by Robert Kimbrough, 251-261. 3rd ed. Norton: New York.

Agamben, Giorgio. 2000. Means without End: Notes on Politics. Translated by Vincenzo Canetti and Cesare Casarino. Theory out of Bounds. Vol. 20. Minneapolis, MN: University of Minnesota Press.

Agamben, Giorgio. 2017. The Omnibus Homo Sacer. Redwood City, CA: Stanford University Press.

Agier, Michel. 2010. "Humanity as an Identity and Its Political Effects (A Note on Camps and Humanitarian Government)." Humanity: an International Journal of Human Rights, Humanitarianism, and Development 1 (1): 29-45. doi:10.1353/hum.2010.0005.

Al-Koni, Ibrahim. 2002. The Bleeding of the Stone. Translated by May Jayyusi and Christopher Tingley. London: Interlink.

Al-Koni, Ibrahim. 2008. Gold Dust. Translated by Elliott Colla. Cairo: American University of Cairo Press.

Asdal, Kristin, Tone Druglitrø, and Steve Hinchliffe, eds. 2017. Humans, Animals and Biopolitics: The More-than-Human Condition. London: Routledge.

Atia, Nadia. 2017. "The Figure of the Refugee in Hassan Blasim's 'The Reality and the Record'." Journal of Commonwealth Literature 1-15. doi:10.1177/0021989417707802.

Bærenholdt, Jørgen Ole. 2013. “Governmobility: The Powers of Mobility.” Mobilities 8: 20-34. doi:10.1080/17450101.2012.747754.

Bahoora, Haytham. 2015. "Writing the Dismembered Nation: The Aesthetics of Horror in Iraqi Narratives of War.” Arab Studies Journal 23 (1): 184-209.

Balibar, Étienne. 2007. “(De)Constructing the Human as Human Institution: A Reflection on the Coherence of Hannah Arendt's Practical Philosophy.” Social Research 74 (3): 727-738.

Blasim, Hassan. 2013. The Iraqi Christ. Translated by Jonathan Wright. London: Comma Press.

Blasim, Hassan. 2016. "Interview with Hassan Blasim." [Margaret Litvin and Johanna Sellman]. Tank, 69. https://tankmagazine.com/issue-69/talk/hassan-blasim

Blasim, Hassan. [2009] 2016. The Madman of Freedom Square. Translated by Jonathan Wright. 2nd ed. London: Comma Press.

Bolaño, Roberto. 2009. 2666. Translated by Natasha Wimmer. London: Picador.

Brown, Wendy. 2005. Edgework: Critical Essays on Knowledge and Politics. Princeton, NJ: Princeton University Press.

Bülent, Diken. 2004. "From Refugee Camps to Gated Communities: Biopolitics and the End of the City." Citizenship Studies 8 (1): 83-106. doi:10.1080/1362102042000178373.

Butler, Judith. 2010. Frames of War: When Is Life Grievable? London: Verso.

Dobson, Kit. 2015. "Neoliberalism and the Limits of the Human: Rawi Hage's Cockroach." Textual Practice 29 (2): 255-271. doi:10.1080/0950236X.2014.993519.

Esposito, Roberto. 2013. Terms of the Political: Community, Immunity, Biopolitics. Translated by Rhiannon Noel Welch. New York: Fordham University Press. 
Farrier, David. 2011. Postcolonial Asylum: Seeking Sanctuary before the Law. Liverpool: Liverpool University Press.

Foucault, Michel. 1977. Discipline and Punish: The Birth of the Prison. London: Vintage.

Foucault, Michel. 1978. The History of Sexuality Volume 1: An Introduction. New York: Random House.

Foucault, Michel. 1986. "Of Other Spaces: Utopias and Heterotopias." Translated by Jay Miskowiec. Diacritics 16 (1): 22-27. doi:10.2307/464648.

Foucault, Michel. 2009. History of Madness. Translated by Jonathan Murphy and Jean Khalfa. London: Routledge.

Foucault, Michel. 2010. The Birth of Biopolitics, Lectures at Collège De France 1978-1979. New York: Picador.

Huggan, Graham, and Helen Tiffin. 2010. Postcolonial Ecocriticism: Literature, Animals, Environment. New York: Routledge.

Khapaeva, Dina. 2012. Nightmare: From Literary Experiment to Cultural Project. Translated by Rosie Tweddle. Leiden, Netherlands: Brill.

Lemke, Thomas. 2011. Biopolitics: An Advanced Introduction. New York: New York University Press.

Lemm, Vanessa, and Miguel Vatter, eds. 2014. The Government of Life: Foucault, Biopolitics, and Neoliberalism. New York: Fordham University Press.

Linguanti, Elsa. 1999. “Introduction.” In Coterminous Worlds: Magical Realism and Contemporary Postcolonial Literature in English, edited by Elsa Linguanti, 1-8. Amsterdam: Rodopi.

McHugh, Susan. 2017. "Loving Camels, Sacrificing Sheep, Slaughtering Gazelles: Human-Animal Relations in Contemporary Desert Fiction.” In Humans, Animals, and Biopolitics: The Morethan-Human Condition, edited by Kristin Asdal, Tone Druglitrø, and Steve Hinchliffe, 171-188. London: Routledge.

Naimou, Angela. 2016. "Double Images: Refugee Crises and the Afterimages of Endless War." College Literature 43 (1): 223-236. doi:10.1353/lit.2016.0004.

Nielsen, Nikolaj. 2017. "Hungary to Detain Asylum Seekers in Shipping Containers." euobserver, March 7. https://euobserver.com/migration/137143.

Owens, Patricia. 2009. “Reclaiming 'Bare Life?': Against Agamben on Refugees.” International Relations 23 (4): 567-582. doi:10.1177/0047117809350545.

Sellman, Johanna. 2014. “The Forests of Exile.” Portal 9, 4. http://portal9journal.org/articles.aspx? $\mathrm{id}=118$.

Sjón and Ted Hodgkinson. 2017. "Introduction." In The Dark Blue Winter Overcoat and Other Short Stories from the North, edited by Sjón and Ted Hodgkinson, 1-4. London: Pushkin Press.

Than, Krisztina. 2017. "Hungary to Arm New 'Border Hunters' after Six-Month Crash Course." Reuters, March 9. https://www.reuters.com/article/us-europe-migrants-hungaryborderhunters/hungary-to-arm-new-border-hunters-after-six-month-crash-course.

Vaughan-Williams, Nick. 2015. Europe's Border Crisis: Biopolitical Security and Beyond. Oxford: Oxford University Press.

Waterton, Claire. 2017. "Indeterminacy and More-Than-Human Bodies: Sites of Experiment for Doing Politics Differently." Special Issue edited by Claire Waterton and Kathryn Yusoff, “Indeterminate Bodies". Body \& Society 23 (1): 102-129. doi:10.1177/1357034X17716522.

Woolley, Agnes. 2014. Contemporary Asylum Narratives: Representing Refugees in the Twentieth Century. London: Palgrave Macmillan.

Yassin-Kassab, Robin. 2013. "Review of the Iraqi Christ." The Guardian, March 20. https://www. theguardian.com/books/2013/mar/20/iraqi-christ-hassan-blasim-review.

Yousef, Farouq. 2007. La Shay' La Ahad: Yawmiyyat fi al-Shamal al-Urubi. [Nothing and nobody: The diary of an Arab in Northern Europe]. Beirut: Al-Mu'assasa al-'arabiyya lildirasa wa al-nashr. 